\title{
Enhanced Current Transportation in Silicon- riched Nitride (SRN)/Silicon-riched Oxide (SRO) Multilayer Nanostructure
}

Yeliao Tao, Jun Zheng, Yuhua Zuo*, Chunlai Xue, Buwen Cheng, Qiming Wang

(Received 16 October; accepted 31 October; published online 10 November 2012.)

\begin{abstract}
A novel structure of silicon-riched nitride (SRN)/silicon-riched oxide (SRO) is proposed and prepared using RF reactive magnetron co-sputtering. High temperature annealing of SRN/SRO multilayers leads to formation of Si nanocrystals (NC) from isolating SRN and SRO layers simultaneously, which efficiently improves carrier transport ability compared to conventional $\mathrm{SRN} / \mathrm{Si}_{3} \mathrm{~N}_{4}$ counterpart. Micro-Raman scattering analysis reveals that SRN layer has dominating number of denser and smaller Si NCs, while SRO layer has relatively less, sparser and bigger Si NCs, as confirmed by high resolution transmission electron microscopy observation. The substitute SRO layers for $\mathrm{Si}_{3} \mathrm{~N}_{4}$ counterparts significantly increase the amount of $\mathrm{Si}$ NCs as well as crystallization ratio in SRN layers; while the average Si NC size can be well controlled by the thickness of SRN layers and the content of N, and hence an obvious stronger absorption in UV region for the novel structure can be observed in absorption spectra. The $I$ - $V$ characteristics show that the current of hybrid SRN/SRO system increases up to 2 orders of magnitude at $1 \mathrm{~V}$ and even 5 orders of magnitude at $4 \mathrm{~V}$ compared to that of $\mathrm{SRN} / \mathrm{Si}_{3} \mathrm{~N}_{4}$ structure. Si NCs in $\mathrm{SiO}_{y}$ layers provide a transport pathway for adjacent $\mathrm{Si} \mathrm{NCs}$ in $\mathrm{SiN}_{\mathrm{x}}$ layers. The obvious advantage in carrier transportation suggests that SRN/SRO hybrid system could be a promising structure and platform to build Si nanostructured solar cells.
\end{abstract}

Keywords: Silicon nanostructure; Magnetron sputtering; Raman Spectroscopy; Charge transport

Citation: Yeliao Tao, Jun Zheng, Yuhua Zuo, Chunlai Xue, Buwen Cheng and Qiming Wang, "Enhanced Current Transportation in Silicon-riched Nitride (SRN)/Silicon-riched Oxide (SRO) Multilayer Nanostructure", Nano-Micro Lett. 4 (4), 202-207 (2012). http://dx.doi.org/10.3786/nml.v4i4.p202-207

\section{Introduction}

Silicon(Si) nanocrystals(NCs) embedded in dielectric matrix like $\mathrm{SiO}_{2}, \mathrm{Si}_{3} \mathrm{~N}_{4}$ or $\mathrm{SiC}$ have attracted interest vis-a-vis all-silicon tandem solar cells $[1,2]$ as well as silicon optoelectronics [3-7]. By utilizing the quantum confinement effect in $\mathrm{Si} \mathrm{NCs}$, an adjustable bandgap can be realized by controlling the NC sizes and hence the electron transfer among the Si NCs. Various deposition techniques have been used to fabricate Si NCs, which involve super-lattice, such as plasmaenhanced chemical vapor deposition (PECVD) [8], and co-sputtering [9]. The radio-frequency (RF) magnetron sputtering technique for Si NC multilayer structure combined with post annealing is considered a costeffective method $[10,11]$.

In order to maximize the efficiency of solar cell, two processes need to be improved. Firstly, denser Si NCs in the multilayer can generate more electron-hole pairs during the absorption process. Secondly, increasing transport ability can extract more charge carriers via front and back contacts in the transport process. Lower bandgap barrier material like $\mathrm{SiC}$ instead of commonly used $\mathrm{SiO}_{2}\left(\mathrm{Si}_{3} \mathrm{~N}_{4}\right)[12,13]$ or ultrathin barriers have been used to increase vertical carrier transport [14]. In this work, a novel structure of silicon-riched ni- 
tride (SRN)/silicon-riched oxide (SRO) is proposed and prepared by $\mathrm{RF}$ reactive magnetron co-sputtering and post-annealing at $1100^{\circ} \mathrm{C}$ in $\mathrm{N}_{2}$ atmosphere. SRO layer is introduced instead of traditional $\mathrm{Si}_{3} \mathrm{~N}_{4}$ one. With $\mathrm{Si}$ $\mathrm{NCs}$ expected in otherwise isolation layer, the carrier transport may be improved. The morphology, absorption and transport properties of the novel SRN/SRO structure have been investigated in detail compared to the conventional SRN $/ \mathrm{Si}_{3} \mathrm{~N}_{4}$ counterpart.

\section{Experimental}

10 pairs of amorphous $3.5 \mathrm{~nm} \mathrm{SiN}_{\mathrm{y}} / 3.5 \mathrm{~nm} \mathrm{SiO}_{\mathrm{x}}$ are deposited on both quartz and $\mathrm{Si}$ substrates by $\mathrm{RF}$ reactive magnetron co-sputtering using computercontrolled KJLC Lab 18 system. The base pressure is $1 \times 10^{-7}$ Torr, and working gas pressure is $3 \mathrm{mTorr}$. The growth temperature is kept as $400^{\circ} \mathrm{C}$. When growing $\mathrm{SiN}_{\mathrm{y}}$ layer, the power density applied to $\mathrm{Si}$ target is $75 \mathrm{~W}$, the gas flux ratio of $\mathrm{N}_{2}$ to $\mathrm{Ar}$ is $4: 100\left(\mathrm{SiN}_{\mathrm{x}}\right)$, 8:100 $\left(\mathrm{SiN}_{\mathrm{x} *}\right)$ or 16:100 $\left(\mathrm{Si}_{3} \mathrm{~N}_{4}\right)$; while in growing $\mathrm{SiO}_{\mathrm{x}}$ layer, the power density applied to $\mathrm{Si}$ and $\mathrm{SiO}_{2}$ targets are $75 \mathrm{~W}$ and $30 \mathrm{~W}$, alternatively. The post annealed procedure is conducted in $\mathrm{N}_{2}$ atmosphere at $1100^{\circ} \mathrm{C}$ for $1 \mathrm{~h}$. For comparison, 10 pairs of $3.5 \mathrm{~nm} \mathrm{SRO} / 3.5 \mathrm{~nm}$

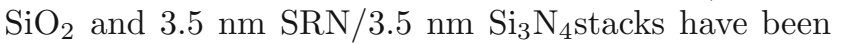
deposited and post-annealed under the same condition.

In order to study the morphology of the stacks, cross-sectional high-resolution transmission electron microscopy (HRTEM) observation was performed by a Tecnai G2 F20 S-Twin with incident electron energy of $200 \mathrm{kV}$. The TEM samples were prepared by standard mechanical and Ar ion thinning techniques. MicroRaman scatting spectra were applied to investigate the microstructure of the films, using the $488 \mathrm{~nm}$ line of Ar ion laser and measured by JobinYvonHR800. For electrical characterization, circular $\mathrm{Al}$ electrodes with diameter of $1 \mathrm{~mm}$ were deposited on the front side of the samples, whereas the back surface of $\mathrm{n}^{+}-\mathrm{Si}$ substrates $\left(\rho=0.001 \Omega \cdot \mathrm{cm}-0.005 \Omega \cdot \mathrm{cm}, \mathrm{n}=0.8 \times 10^{20}\right.$ $\mathrm{cm}^{-3}-1 \times 10^{20} \mathrm{~cm}^{-3}$, thickness $\left.=400 \mu \mathrm{m}\right)$ was entirely covered with $\mathrm{Al}$ as the rear contact. The devices were annealed at $450^{\circ} \mathrm{C}$ for $0.5 \mathrm{~h}$ in $\mathrm{N}_{2}$ atmosphere to improve the contact properties at the interface of $\mathrm{Si} \mathrm{NC}$ layers/electrode. The current density as a function of the applied voltage was measured using a Suss PM8 probe station connected to an Agilent B1500A semiconductor parameter analyzer.

\section{Results and discussion}

\section{HRTEM analysis}

Figure 1 shows TEM micrographs of the annealed $\mathrm{SiN}_{\mathrm{x}} / \mathrm{SiO}_{\mathrm{y}}$ sample. The total thickness of $75 \mathrm{~nm}$ is slightly larger as compared with the designed value of $70 \mathrm{~nm}$. After thermal annealing, the periodic structure of the stack is not clear as shown in Fig. 1(a), due to the precipitation of excess Si nanocrystals (NCs) from both $\mathrm{SiN}_{\mathrm{x}}$ and $\mathrm{SiO}_{\mathrm{y}}$ layers. Figure 1(b) depicts a high-resolution TEM image of Si NCs. The lattice fringes correspond to isolated $\mathrm{Si} \mathrm{NCs}$, while the surrounding speckle pattern corresponds to amorphous $\mathrm{SiO}_{2}$ or $\mathrm{Si}_{3} \mathrm{~N}_{4}$. The average density of $\mathrm{Si} \mathrm{NCs}$ is about $7 \times 10^{11} \mathrm{~cm}^{-2}$. Most of Si NCs are well confined in each isolated $\mathrm{SiN}_{\mathrm{x}}$ or $\mathrm{SiO}_{\mathrm{y}}$ layers, and some larger $\mathrm{Si}$ $\mathrm{NC}$ penetrates both $\mathrm{SiN}_{\mathrm{x}}$ and $\mathrm{SiO}_{\mathrm{y}}$ layers, which will be discussed later. However, one should notice that the distribution of $\mathrm{Si} \mathrm{NC}$ shows a very different behavior in different isolation layer. The density of Si NCs in $\mathrm{SiN}_{\mathrm{x}}$ layers is larger than that in $\mathrm{SiO}_{\mathrm{y}}$ layers, while the average size of $\mathrm{Si} \mathrm{NCs}$ in $\mathrm{SiN}_{\mathrm{x}}$ layer of $2.7 \mathrm{~nm}$ is smaller than that in $\mathrm{SiO}_{y}$ layers of $3.5 \mathrm{~nm}$. That is, larger and sparser $\mathrm{Si} \mathrm{NC}$ exists in $\mathrm{SiO}_{\mathrm{y}}$ layer, while smaller and denser $\mathrm{Si} \mathrm{NC}$ exists in $\mathrm{SiN}_{\mathrm{x}}$ layer. The phenomena can be also observed in the following Micro-Raman analyzes. The origin will be discussed there.

\section{Micro-Raman scattering spectra}

Figure 2 shows Micro-Raman scattering spectra of all samples on quartz substrates, including standard c-Si substrate and as-deposited $\mathrm{SiN}_{\mathrm{x}} / \mathrm{SiO}_{\mathrm{y}}$ sample. The

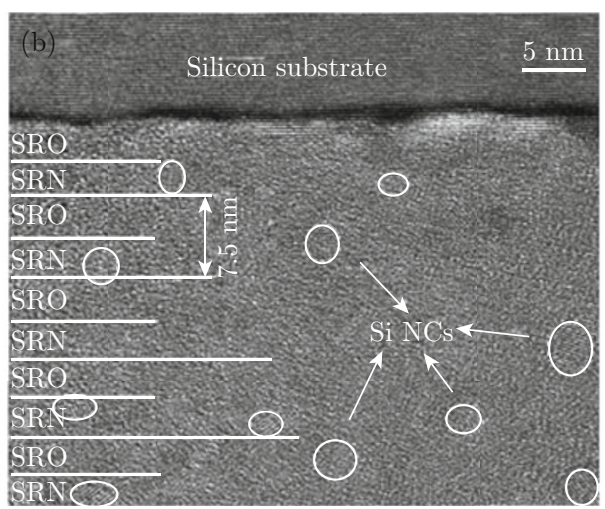

Fig. 1 TEM images of $\mathrm{Si}$ NCs of annealed $\mathrm{SiN}_{\mathrm{x}} / \mathrm{SiO}_{\mathrm{y}}$ sample: (a) Low-magnification image and (b) High-resolution image. 


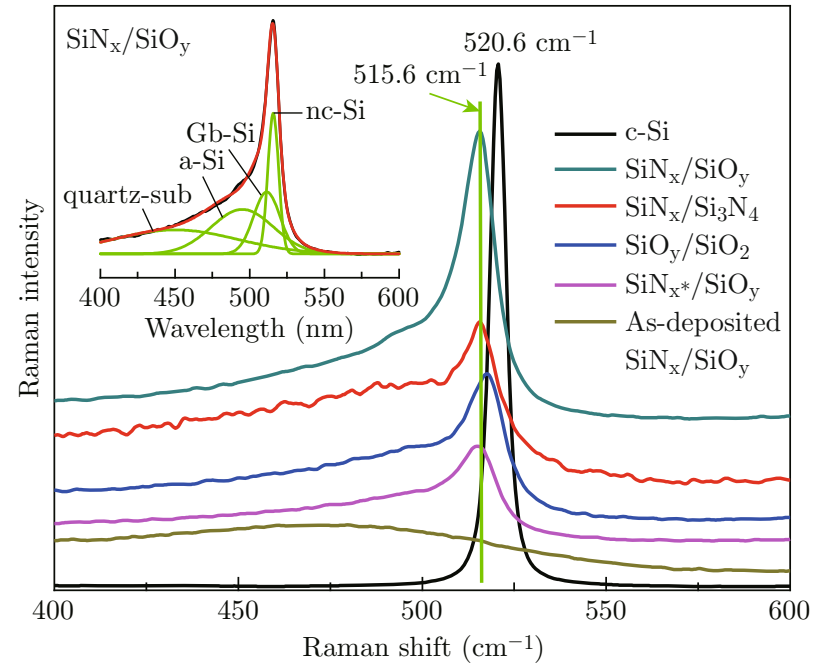

Fig. 2 Raman scattering spectra of all type of Si NCs structures and the Gaussian deconvoluted spectra of $\mathrm{SiN}_{\mathrm{x}} / \mathrm{SiO}_{\mathrm{y}}$ sturcture.

as-deposited $\mathrm{SiN}_{\mathrm{x}} / \mathrm{SiO}_{\mathrm{y}}$ film remains the amorphous phase characterized by the broadband peak centered at around $480 \mathrm{~cm}^{-1}[15]$; after annealing at $1100^{\circ} \mathrm{C}$, a transition from amorphous to crystalline phase occurs through random nucleation of Si NC surrounded by $a$ $\mathrm{Si}$, as indicated by the emergence of an intense peak with a frequency downshift compared to bulk Si Raman scattering spectra [16]. This frequency downshift may be caused by grain size related effect and compressive stress in the thin films $[17,18]$. Neglecting the stress effect, according to Zi's confinement model [19]: $\Delta \omega=\omega\left(D_{z}\right)-\omega_{0}=-A\left(a / D_{z}\right)^{\gamma}$, where $\omega\left(D_{z}\right)$ is the frequency of the Raman phonon in a nanocrystal with size $D_{z}, \omega_{0}\left(520.6 \mathrm{~cm}^{-1}\right)$ is the frequency of the optical phonon at the zone center for bulk crystal $\mathrm{Si}$, and $a$ is the lattice constant of $\mathrm{Si}(0.543 \mathrm{~nm})$. The parameters $A$ and $\gamma$, used to describe the vibration confinement due to the finite size in a nanocrystal, are $47.41 \mathrm{~cm}^{-1}$ and 1.44, respectively. In this way, the sizes of Si NCs in four annealed samples can be obtained as summarized in Table 1.

Table 1 The list of analysis results of Raman scattering spectra

\begin{tabular}{ccccc}
\hline Structure & $\begin{array}{c}\text { Peak position } \\
\left(\mathrm{cm}^{-1}\right)\end{array}$ & $D(\mathrm{~nm})$ & $X_{g b}(\%)$ & $\begin{array}{c}F n \\
\text { (at.\%) }\end{array}$ \\
\hline $\mathrm{SiO}_{\mathrm{y}} / \mathrm{SiO}_{2}$ & 517.7 & 3.28 & 26.6 & 46.3 \\
$\mathrm{SiN}_{\mathrm{x}} / \mathrm{Si}_{3} \mathrm{~N}_{4}$ & 515.6 & 2.58 & 24.6 & 36.2 \\
$\mathrm{SiN}_{\mathrm{x}} / \mathrm{SiO}_{\mathrm{y}}$ & 515.6 & 2.58 & 26.5 & 50.9 \\
$\mathrm{SiN}_{\mathrm{x} *} / \mathrm{SiO}_{\mathrm{y}}$ & 514.7 & 2.41 & 24.2 & 42.8 \\
\hline
\end{tabular}

Besides the peak coming from quartz substrate, the Raman scattering spectra of annealed $\mathrm{SiN}_{\mathrm{x}} / \mathrm{SiO}_{\mathrm{y}}$ can be well deconvoluted into three Gaussian components, as shown in the inset of Fig. 2. The first peak in the region $460-490 \mathrm{~cm}^{-1}$ comes from the TO vibrational modes of amorphous silicon. The second one, the intermediate component, arises near $505 \mathrm{~cm}^{-1}$ associated with the bond dilation at grain boundaries. The third region at $515-517 \mathrm{~cm}^{-1}$ is assigned to the TO mode of crystal grains of different sizes [18]. The crystalline and grain boundary volume fractions, $F_{n}$, and $X_{g b}$ can be estimated from $F_{n}=\left(I_{n}+I_{g b}\right) /\left(\beta I_{a}+I_{g b}+I_{n}\right)$, $X_{g b}=I_{g b} /\left(\beta I_{a}+I_{g b}+I_{n}\right)$. Where $I_{a}, I_{g b}$ and $I_{n}$ are integrated intensities of the amorphous, intermediate and nanocrystalline peaks, respectively, and $\beta$ represents the ratio of the cross section of the amorphous to crystalline phase, which varies with the grain size $D, \beta=0.1+\exp (-D / 250)[20]$. Using the $D$ value calculated before, we obtain the crystalline volume fraction $F_{n}$ listed in Table 1.

We notice that the average $\mathrm{Si}$ NCs size of $\mathrm{SiN}_{\mathrm{x}} / \mathrm{SiO}_{\mathrm{y}}$ structure are the same as that of $\mathrm{SiN}_{\mathrm{x}} / \mathrm{Si}_{3} \mathrm{~N}_{4}$ structure, with the value of $2.58 \mathrm{~nm}$, while it is smaller than that in $\mathrm{SiO}_{\mathrm{y}} / \mathrm{SiO}_{2}$ counterpart with the value of 3.28 $\mathrm{nm}$. It means $\mathrm{Si} \mathrm{NCs}$ in $\mathrm{SiO}_{\mathrm{y}}$ layers have little impact on the average size of $\mathrm{Si} \mathrm{NCs}$ in $\mathrm{SiN}_{\mathrm{x}} / \mathrm{SiO}_{\mathrm{y}}$ structure, indicating that $\mathrm{Si}$ NCs are well confined in the isolated layers and the $\mathrm{NC}$ size in $\mathrm{SiN}_{\mathrm{x}}$ layer dominates the average size since the number of $\mathrm{NCs}_{\mathrm{S}}$ in $\mathrm{SiN}_{\mathrm{x}}$ layer is much more than that in $\mathrm{SiO}_{\mathrm{y}}$ layer. It can be concluded that the Si NCs in $\mathrm{SiN}_{\mathrm{x}}$ layer is denser and smaller, while that in $\mathrm{SiO}_{\mathrm{y}}$ layer is sparser and bigger. The result is consistent with the HRTEM observation.

Another important feature is that the crystalline volume fraction $F_{n}$ of $\mathrm{SiN}_{\mathrm{x}} / \mathrm{SiO}_{\mathrm{y}}$ structure, with the value of $50.9 \%$, is obviously higher than $46.3 \%$ of $\mathrm{SiO}_{y} / \mathrm{SiO}_{2}$ structure and $36.2 \%$ of $\mathrm{SiN}_{\mathrm{x}} / \mathrm{Si}_{3} \mathrm{~N}_{4}$ structure. Meanwhile, $F_{n}$ decreases from $50.9 \%$ to $42.8 \%$, along with the NC size reducing from $2.58 \mathrm{~nm}$ to $2.41 \mathrm{~nm}$, when $\mathrm{Si}$ rich degree decreases with the concentration of nitrogen increasing from $\mathrm{x}$ to $x^{*}$. The higher $F_{n}$ and more Si NCs in $\mathrm{SiN}_{\mathrm{x}}$ layer may be explained by directional aggregation due to the distinguished difference of bond energy between $\mathrm{Si}-\mathrm{N}(439 \mathrm{~kJ} / \mathrm{mol})$ and $\mathrm{Si}-\mathrm{O}(799.6 \mathrm{~kJ} / \mathrm{mol})$. It was reported that nucleation of c-Si is suppressed near the $\mathrm{Si} / \mathrm{SiO}_{2}$ interface in the adjacent $0.5-1.0 \mathrm{~nm}$ of the Si layer [21]. However, during annealing procedure, the $\mathrm{Si}$ atoms near the $\mathrm{SiN}_{\mathrm{x}} / \mathrm{SiO}_{\mathrm{y}}$ interfaces are in a trend to move to $\mathrm{SiN}_{\mathrm{x}}$ layers to form a $\mathrm{Si} \mathrm{NC}$ due to smaller Si-N bond energy, about only half of Si-O counterpart. Therefore, Si NCs can nucleate instead of being suppressed near the $\mathrm{SiN}_{\mathrm{x}} / \mathrm{SiO}_{\mathrm{y}}$ interface, resulting in higher $F_{n}$. In some cases, one can expect large Si NC penetrates both layers, which can be confirmed by the HRTEM image in Fig. 1(b).

In conclusion, in $\mathrm{SiN}_{\mathrm{x}} / \mathrm{SiO}_{\mathrm{y}}$ structure, compared to conventional $\mathrm{SiO}_{\mathrm{y}} / \mathrm{SiO}_{2}$ and $\mathrm{SiN}_{\mathrm{x}} / \mathrm{Si}_{3} \mathrm{~N}_{4}$ structure, the number of Si NCs in $\mathrm{SiN}_{\mathrm{x}}$ increases significantly while that of $\mathrm{Si}$ NCs in $\mathrm{SiO}_{\mathrm{y}}$ reduces and the total crystalline volume fraction is also improved. The $\mathrm{SiN}_{\mathrm{x}}$ layer is the 
dominating one, and both $\mathrm{NC}$ size and crystalline volume fraction of the novel $\mathrm{SiN}_{\mathrm{x}} / \mathrm{SiO}_{\mathrm{y}}$ structure can be well controlled by the thickness of $\mathrm{SiN}_{\mathrm{x}}$ layer. Furthermore, the increasing number of $\mathrm{Si} \mathrm{NCs}_{\mathrm{in}} \mathrm{SiN}_{\mathrm{x}}$ layers and existence of $\mathrm{Si} \mathrm{NCs}$ in both $\mathrm{SiN}_{\mathrm{x}}$ and $\mathrm{SiO}_{\mathrm{y}}$ layers can substantially improve the transport properties which we will discuss later.

\section{Optical properties}

To clarify the impact of the substitute SRO layers for $\mathrm{Si}_{3} \mathrm{~N}_{4}$ layers on optical properties, the optical bandgap energy of $\mathrm{SiN}_{\mathrm{x}} / \mathrm{SiO}_{\mathrm{y}}, \mathrm{SiN}_{\mathrm{x}} / \mathrm{Si}_{3} \mathrm{~N}_{4}$ and $\mathrm{SiN}_{\mathrm{x} *} / \mathrm{SiO}_{\mathrm{y}}$ samples is determined using Tauc's Equation [22], given as: $\alpha h \nu=B^{\text {tauc }}\left(h \nu-E_{\text {gopt }}\right)^{2}$. Where $\alpha$ is the absorption coefficient, $h$ is Plank's constant, and $\nu$ is the frequency of the radiation. $B^{\text {tauc }}$ is the edge width parameter. $\alpha$ can be determined from the transmission and reflectance spectra, which is not shown here. Figure 3 shows the plot of $\alpha h \nu^{1 / 2}$ versus photon energy h of these samples. $E_{\text {gopt }}$ evaluated from extrapolation of a linear part of the curve to intersect the energy axis $(\alpha h \nu=0)$. There is evidence that the absorption edge is all about $2.1 \mathrm{eV}$ for these three samples which means the size of Si NCs is constant.

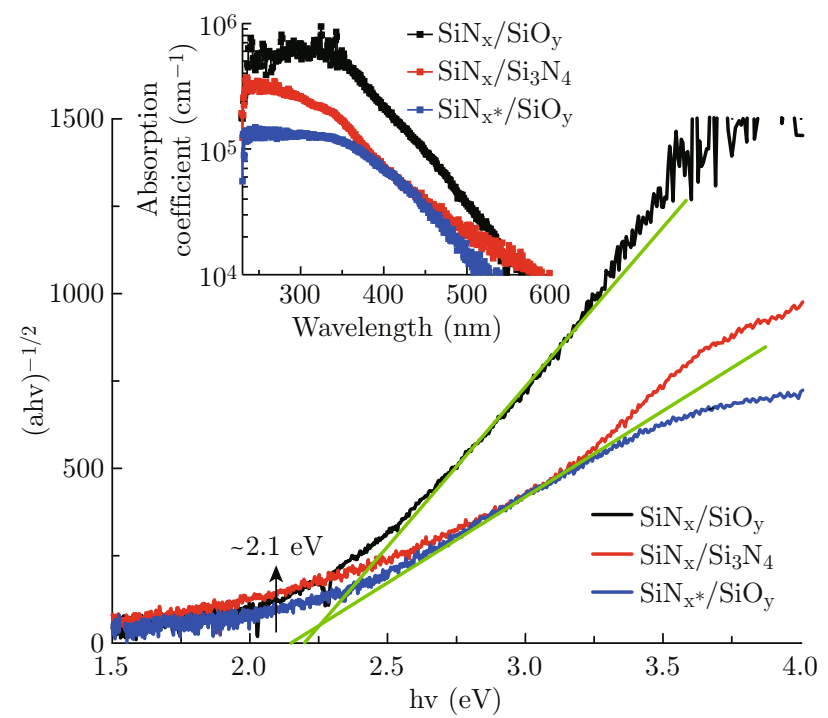

Fig. 3 Plot of $(a h v)^{1 / 2}$ versus photon energy. The green lines are a fit of the Tauc curves. The inset illustrates the absorption coefficient of $\mathrm{SiN}_{\mathrm{x}} / \mathrm{SiO}_{\mathrm{y}}, \mathrm{SiN}_{\mathrm{x}} / \mathrm{Si}_{3} \mathrm{~N}_{4}$ and $\mathrm{SiN}_{\mathrm{x} *} / \mathrm{SiO}_{\mathrm{y}}$ samples.

The inset of Fig. 3 illustrates the absorption coefficient of $\mathrm{SiN}_{\mathrm{x}} / \mathrm{SiO}_{\mathrm{y}}, \mathrm{SiN}_{\mathrm{x}} / \mathrm{Si}_{3} \mathrm{~N}_{4}$ and $\mathrm{SiN}_{\mathrm{x} *} / \mathrm{SiO}_{\mathrm{y}}$ samples. The $\mathrm{SiN}_{\mathrm{x}} / \mathrm{SiO}_{\mathrm{y}}$ sample has an obvious stronger absorption in UV region due to more $\mathrm{Si} \mathrm{NCs}_{\mathrm{S}}$ in $\mathrm{SiN}_{\mathrm{x}}$ layers. Compared with the $\mathrm{SiN}_{\mathrm{x}} / \mathrm{Si}_{3} \mathrm{~N}_{4}$ and $\mathrm{SiN}_{\mathrm{x} *} / \mathrm{SiO}_{\mathrm{y}}$ samples, the increased Si NCs can be explained by two reasons: (1) more $\mathrm{Si}$ atoms in $\mathrm{SiN}_{\mathrm{x}}$ layers by controlling the $\mathrm{Si} / \mathrm{N}$ ratio; (2) using $\mathrm{SiO}_{\mathrm{y}}$ layer as a substitute for
$\mathrm{Si}_{3} \mathrm{~N}_{4}$ layer. The absorption coefficient result is corresponding to the Raman spectra analysis.

\section{Electrical characterization}

Figure 4 shows the $J-V$ characteristics of annealed $\mathrm{SiN}_{\mathrm{x}} / \mathrm{Si}_{3} \mathrm{~N}_{4}, \mathrm{SiN}_{\mathrm{x}} / \mathrm{SiO}_{\mathrm{y}}$ and $\mathrm{SiN}_{\mathrm{x} *} / \mathrm{SiO}_{\mathrm{y}}$ samples at room temperature. Hysteresis effect is not observed when the voltage is swept in forward direction and back to $0 \mathrm{~V}$, which means the charging or electrically driven diffusion process of metal into films does not influence the $J-V$ characteristics. As we expect, the hybrid $\mathrm{SiN}_{\mathrm{x}} / \mathrm{SiO}_{\mathrm{y}}$ system shows a huge increase up to 2 orders of magnitude at $1 \mathrm{~V}$ and even 5 orders of magnitude at $4 \mathrm{~V}$ compared to $\mathrm{SiN}_{\mathrm{x}} / \mathrm{Si}_{3} \mathrm{~N}_{4}$ structure. The current decreases obviously when Si rich degree in $\mathrm{SiN}_{\mathrm{x}}$ layer decreases.

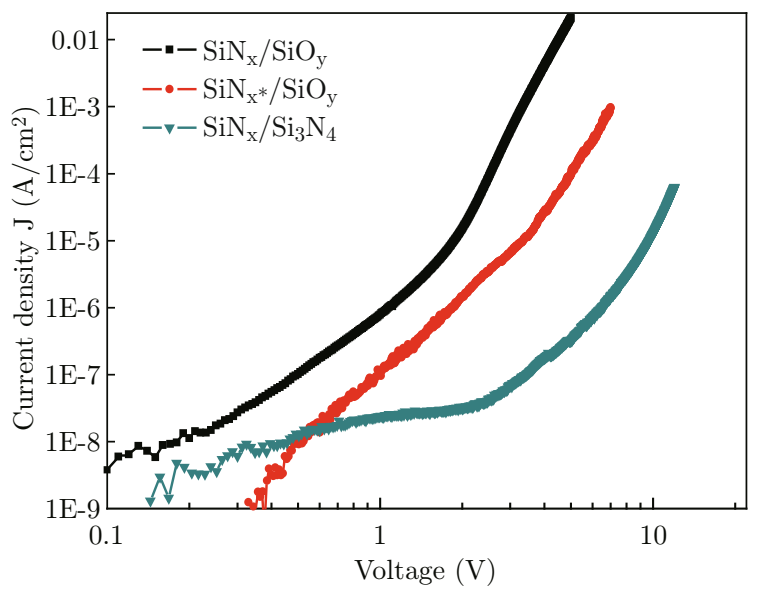

Fig. 4 The $J-V$ curves of annealed $\mathrm{SiN}_{\mathrm{x}} / \mathrm{Si}_{3} \mathrm{~N}_{4}, \mathrm{SiN}_{\mathrm{x}} / \mathrm{SiO}_{\mathrm{y}}$ and $\mathrm{SiN}_{\mathrm{x} *} / \mathrm{SiO}_{\mathrm{y}}$ samples at room temperature.

Temperature dependent $I-V$ was implemented to clarify the transport mechanisms of these samples. The inset of Fig. 5 shows effect of temperature on the $J-V$ characteristics of $\mathrm{SiN}_{\mathrm{x}} / \mathrm{SiO}_{\mathrm{y}}$ sample at high electrical field (applied voltage $>1 \mathrm{~V}$ ). Due to the temperature dependence of the current, models of tunneling mechanism cannot be used to explain the transport properties of these samples, such as the direct tunneling [23], the Fowler-Nordheim tunneling [24], or the trapassisted tunneling [25]. But the temperature behavior and voltage dependence indicate that Poole-Frenkel emission, which is based on the emission of trapped electrons towards the dielectric conduction band, can best describe the transport properties. Figure 5 shows the $J / V-V^{1 / 2}$ plots of all samples at room temperature. The Poole-Frenkel emission is governed by following equation:

$$
J_{P F} \propto V \exp \left[-(q / n k T)\left(\varphi_{t}-\sqrt{q V / d \pi \varepsilon}\right)\right]
$$




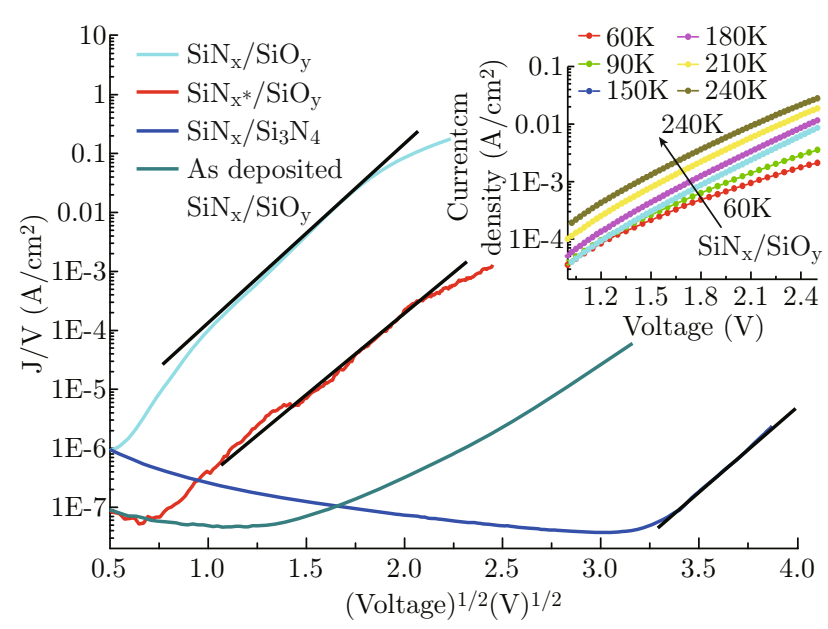

Fig. 5 The Poole-Frenkel plot of annealed $\mathrm{SiN}_{\mathrm{x}} / \mathrm{Si}_{3} \mathrm{~N}_{4}$, $\mathrm{SiN}_{\mathrm{x}} / \mathrm{SiO}_{\mathrm{y}}$ and $\mathrm{SiN}_{\mathrm{x} *} / \mathrm{SiO}_{\mathrm{y}}$ samples showing a straight line at high voltage region. The as-deposited $\mathrm{SiN}_{\mathrm{x}} / \mathrm{SiO}_{\mathrm{y}}$ sample do not shows P-F emission properties. The inset illustrate the temperature dependent $J-V$ curves of $\mathrm{SiN}_{\mathrm{x}} / \mathrm{SiO}_{\mathrm{y}}$ structure for the high voltage region $(V>1 \mathrm{~V})$.

$J_{P F}$ is the current density, $q$ the electronic charge, $d$ is the oxide and nitride thickness, $k$ the Boltzmann constant, $T$ the absolute temperature, $\phi_{t}$ the potential barrier at the trap/dielectric interface (at zero field), and $\varepsilon$ is the dielectric constants, respectively. The asdeposited $\mathrm{SiN}_{\mathrm{x}} / \mathrm{SiO}_{\mathrm{y}}$ sample does not show a PF emission property. The slope of the plot of $\log (I / V)$ versus $V^{1 / 2}$, which is called Poole-Frenkel plot, is indicated by linear regression through the data points in Fig. 5 . These slopes will yield the dielectric constant of samples under test. However, for these samples, due to the hybrid nature of the $\mathrm{Si}$ NCs embedded in $\mathrm{Si}_{3} \mathrm{~N}_{4}$ or $\mathrm{SiO}_{2}$ dielectric layers, the thickness of total dielectric layers can be hardly determined and this makes it difficult to get the real numerical dielectric constants directly from the slopes. Further work is undergoing to investigate the details of the transport mechanism of the novel structure.

In a silicon tandem solar cell, good charge carrier transport between $\mathrm{Si}$ NCs is important for the upper solar cell. The present investigation of the $\mathrm{SiN}_{\mathrm{x}} / \mathrm{SiO}_{\mathrm{y}}$ hybrid system demonstrates that $\mathrm{Si}$ NCs of different sizes embedded in isolated layers provides a significantly increase of transport properties. Compared to the conventional $\mathrm{SiN}_{\mathrm{x}} / \mathrm{Si}_{3} \mathrm{~N}_{4}$ structure, the larger $\mathrm{Si} \mathrm{NCs}$ in $\mathrm{SiO}_{\mathrm{y}}$ layers provide a "pathway" of carrier transportation, as shown in Fig. 6. The present of $\mathrm{Si} \mathrm{NCs}$ in $\mathrm{SiO}_{y}$ significantly decrease distance between the closest NCs on vertical direction, and increase tunneling ability. Furthermore, $\mathrm{SiO}_{y}$ layer acts as "supplying layer" to provide more $\mathrm{Si}$ atoms to $\mathrm{SiN}_{\mathrm{x}}$ layer, making $\mathrm{Si}$ NCs number in $\mathrm{SiN}_{\mathrm{x}}$ increase. With increasing Si NCs number in $\mathrm{SiN}_{\mathrm{x}}$ layers, absorption improves, generating more electron-hole pairs; meanwhile, denser Si NCs make the photon-induced carriers find the "pathway" easier and have higher tunneling probability, improving the carrier extracting ability. That is why $\mathrm{SiN}_{\mathrm{x}} / \mathrm{SiO}_{\mathrm{y}}$ structure has more efficient transport ability compared to $\mathrm{SiN}_{\mathrm{x}} / \mathrm{Si}_{3} \mathrm{~N}_{4}$ counterpart.

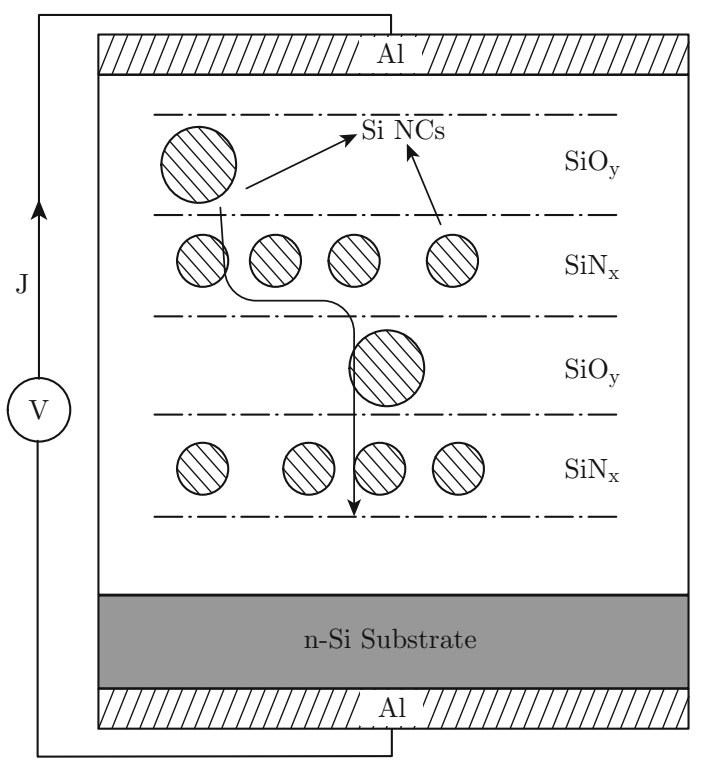

Fig. 6 Schematic transport model of the $\mathrm{SiN}_{\mathrm{x}} / \mathrm{SiO}_{\mathrm{y}}$ system.

\section{Conclusion}

The fabrication of Si NCs embedded in a novel $\mathrm{SiN}_{\mathrm{x}} / \mathrm{SiO}_{\mathrm{y}}$ structure using radio frequency magnetron sputtering has been demonstrated. The TEM and Raman spectra clearly indicate that Si NCs appear in each isolated layers, and the presentation of $\mathrm{SiO}_{\mathrm{y}}$ layer increase the crystallization volume fraction of $\mathrm{SiN}_{\mathrm{x}}$ layers. More Si NCs in this structure obviously enhance the absorption coefficient in ultra-violet region. $J-V$ result indicates that $\mathrm{Si}$ NCs in $\mathrm{SiO}_{\mathrm{y}}$ layers provide a transport "pathway" for adjacent $\mathrm{Si} \mathrm{NCs}$ in $\mathrm{SiN}_{\mathrm{x}}$ layers. The structures consisting of Si NCs in isolated layers can significantly improve the collection of charge carriers and consequently enhance the efficiency of tandem all-Si solar cells.

\section{Acknowledgments}

This work was supported by the National Natural Science Foundation of China (No. 61036001, 51072194 and 60906035)

\section{References}

[1] M. A. Green, "Third Generation photovoltaics", Springer, Berlin (2003).

[2] G. Conibeer, M. A. Green, R. Corkish, Y. Cho, E. C. Cho, C. W. Jiang, T. Fangsuwannarak, E. Pink, Y. Huang, T. Puzzer, T. Trupke, B. Richards, A. 
Shalav and K. L. Lin, Thin Solid Films 511, 654 (2006). http://dx.doi.org/10.1016/j.tsf.2005.12.119

[3] H. L. Hwang etc, "Handbook of Semiconductor Nanostructures and Nanodevices", American Scientific Publishers (2006).

[4] T. Jie, J. W. Shi, L. L.Zhou and Zh. Q. Ma, NanoMicro Lett. 3, 129 (2011). http://dx.doi.org/10. 3786/nml . v3i2 . p129-134

[5] F. Gourbilleau, C. Ternon, D. Maestre, O. Palais and C. Dufour, J. Appl. Phys. 106, 013501 (2009). http:// $\mathrm{dx}$.doi.org/10.1063/1.3156730

[6] L. Pavesi, L. D. Negro, C. Msxxoleni, G. Franz and F. Priolo, Nature 408, 440 (2000). http://dx.doi.org/ 10.1038/35044012

[7] D. Lu, H. D. Li, S. H. Cheng, J. J. Yuan and X. Y. Lv, Nano-Micro Lett. 2, 56 (2010). http://dx.doi.org/ 10.5101/nml.v2i1.p56-59

[8] D. Pacifici, G. Franz, F. Priolo, F. Iacona and L. D. Negro, Phys. Rev. B 67, 245301 (2003). http://dx. doi.org/10.1103/PhysRevB.67.245301

[9] S. Takeoka, M. fujii and S. Hayashi, Phy. Rev. B 62, 16820 (2000). http://dx.doi.org/10.1103/ PhysRevB.62.16820

[10] N. M. Park, T. S. Kim and S. J. Park, Appl. Phys. Lett. 78, 2575 (2001). http://dx.doi.org/10.1063/ 1. 1367277

[11] J. H. Kim and P. H. Holloway, J. Appl. Phys. 95, 4787 (2004). http://dx.doi.org/10.1063/1.1652226

[12] C. W. Jiang and M. A. Green, J. Appl. phys. 99, 114902 (2006). http://dx.doi.org/+10.1063/1. 2203394

[13] M. A. Green, G. Conibeer, D. König, E. C. Cho, D. Song, Y. Cho, T. Fangsuwannar-ak, Y. Huang, G. Scardera, E. Pink, S. Huang, C. Jiang, T. Trupke, R. Corkish and T. puzzer, Proceedings of the $21^{\text {st }} \mathrm{Eu}-$ ropean Photovoltaic Solar Energy Conference. p10-14 (2006).
[14] B. Berghoff, S. Suckow, R. Rölver, B. Spangenberg, H. Kurz, A. Sologubenko and J. Mayer, Sol. Energy Mater. Sol. Cells 94, 1893 (2010). http://dx.doi.org/ 10.1016/j.solmat.2010.06.033

[15] M. Marinov and N. Zotov, Phys. Rev. B 55, 2938 (1997). http://dx.doi.org/10.1103/PhysRevB. 55.2938

[16] G. Faraci, S. Gibilisco, P. Russo, A. R. Pennisi and S. La Rosa, Phys. Rev. B 73, 033307 (2006). http://dx. doi.org/10.1103/PhysRevB.73.033307

[17] Ch. Ossadnik, S. Veprek and I. Gregora, Thin. Solid. Films 337, 148 (1999). http://dx.doi.org/10.1016/ S0040-6090 (98) 01175-4

[18] S. Veprek, F.A. Sarott, Phys. Rev. B 36, 3344 (1987). http://dx.doi.org/10.1103/PhysRevB.36.3344

[19] J. Zi, H. Buscher, C. Falter, W. Ludwig, K. Zhang and X. Xie, Appl. Phys. Lett. 69, 200 (1996). http://dx. doi.org/10.1063/1.117371

[20] E. Bustarret, M. A. Hachicha and M. Brunel, Appl. Phys. Lett. 52, 1675 (1988). http://dx.doi.org/10. 1063/1.99054

[21] J. Gonzalez-Hernandez and R. Tsu, Appl. Phys. Lett. 42, 90 (1983). http://dx.doi.org/10.1002/ pssb. 19660150224

[22] J. Tauc, R. Grigorovici and A. Vancu, Phys. Status. Solidi 15, 627 (1966). http://dx.doi.org/10.1002/ pssb. 19660150224

[23] S. M. Sze, "Physics of Semiconductor Devices", Wiley, New York (1981).

[24] R. H. Fowler and L. Nordheim, Proc. R. Soc. A. 119, 173 (1928).

[25] B. Riccò, G. Gozzi and M. Lanzoni, IEEE Trans. Electron. Devices 45, 1554 (1998). http://dx.doi.org/ $10.1109 / 16.701488$ 